\title{
DESCRIPTION OF A NEW METHOD OF MEASURING THE PELVIC INCIDENCE ANGLE THROUGH COMPUTED TOMOGRAPHY
}

\author{
DESCRIÇÃO DE UM NOVO MÉTODO PARA MEDIÇÃO DO ÂNGULO DE INCIDÊNCIA PÉLVICA \\ ATRAVÉS DE TOMOGRAFIA COMPUTADORIZADA
}

\section{DESCRIPCIÓN DE UN NUEVO MÉTODO PARA MEDICIÓN DEL ÁNGULO DE INCIDENCIA PÉLVICA A TRAVÉS DE TOMOGRAFÍA COMPUTARIZADA}

\author{
Murilo Tavares Daher, ${ }^{1,2}$ Renato Fleury di Souza Lopes, ${ }^{2}$ Renato Tavares Daher, ${ }^{2,3}$ Ricardo Tavares Daher, ${ }^{2}$ Nilo Carrijo Melo, ${ }^{2}$ Vinício Nunes Nascimento, ${ }^{2}$ \\ Pedro Felisbino JR, ${ }^{2}$ Ricardo Vieira Teles Filho, ${ }^{4}$ Marcelo Fouad Rabahi ${ }^{5}$
}

\author{
1. Universidade Federal de Goiás, Faculdade de Medicina, Department of Orthopedics and Traumatology - DOT/FM/UFG, Goiânia, GO, Brazil. \\ 2. Centro de Reabilitação e Readaptacão Dr. Henrique Santillo - CRER, Spine Group, Goiânia, GO, Brazil. \\ 3. Universidade Federal de Goiás, Faculdade de Medicina, Department of Radiology - DR/FM/UFG, Goiânia, GO, Brazil. \\ 4. Universidade Federal de Goiás, Faculdade de Medicina - FM/UFG, Goiânia, GO, Brazil. \\ 5. Universidade Federal de Goiás, Faculdade de Medicina, Department of Clinical Medicine - DR/FM/UFG, Goiânia, GO, Brazil.
}

\begin{abstract}
Objective: To describe a more accurate method for measuring the pelvic incidence angle using computed tomography, without the influence of the positioning of the pelvis in relation to the X-ray tube. Methods: Thirteen CT scans of the lumbosacral region, abdomen or pelvis were randomly assessed, as all these exams include the sacrum and femoral heads. All the exams were performed in multichannel devices with six channels. The technique of overlapping images, already common in other musculoskeletal exams, such as TT-TG, was used. The centered sagittal cut of the left femoral head, the center of S1, and the right femoral head were used. From these, a fourth image was created, analogous to an X-ray of the pelvis, from which measurements were taken using the dedicated software. Results: Of the thirteen exams, three were of the lumbar spine and 10 were of the total abdomen, six of them being of males.. The mean age was 56 years. The mean $\mathrm{PI}$ was $45^{\circ}$, ranging from 31 to 81 degrees. Among the women, the mean was $52^{\circ}\left(31\right.$ to $\left.81^{\circ}\right)$ and among the men, $38^{\circ}\left(32\right.$ to $\left.46^{\circ}\right)$. Conclusion: CT can be used to calculate the PI, using the technique of overlapping images common to other musculoskeletal exams, such as TT-TG. Level of Evidence IIIB. Diagnostic study; Retrospective study.
\end{abstract}

Keywords: Tomography, X-Ray Computed; Spine; Scoliosis; Diagnostic imaging.

\section{RESUMO}

Objetivo: Descrever um método mais preciso para medição do ângulo de incidência pélvica, utilizando a tomografia computadorizada, sem influência do posicionamento da pelve em relação à ampola de raio-x. Métodos: Foram avaliados, de modo aleatório, 13 exames de TC da coluna lombossacra, abdome total ou pelve, já que englobam o sacro e as cabeças femorais. Todos os exames foram realizados em aparelhos multicanais com 6 canais. Utilizou-se a técnica de sobreposição de imagens, comum em outros exames musculoesqueléticos como TT-TG. Foi selecionado o corte sagital centrado da cabeça femoral esquerda, centro do platô de S1 e cabeça femoral direita. A partir de então, foi criada uma quarta imagem, análoga a uma radiografia da pelve, em que foram realizadas as medidas, utilizando o software dedicado. Resultados: Dos 13 exames, três eram da coluna lombar e 10 do abdome total, sendo que seis eram do sexo masculino. A média de idade foi de 56 anos. A média da IP foi de $45^{\circ}$, variando entre 31 e 81 . Entre as mulheres, a média foi de $52^{\circ}\left(31^{\circ}\right.$ a $\left.81^{\circ}\right)$ e entre os homes de $38^{\circ}\left(32^{\circ}\right.$ e $\left.46^{\circ}\right)$. Conclusão: A TC pode ser utilizada para o cálculo da IP, utilizando a técnica de sobreposição de imagens comum em outros exames musculoesqueléticos como TT-TG. Nível de Evidência IIIB. Estudo diagnóstico. Estudo retrospectivo.

Descritores: Tomografia computadorizada por raios X; Coluna vertebral; Escoliose; Diagnóstico por imagem.

\section{RESUMEN}

Objetivo: Describir un método más preciso para medición del ángulo de incidencia pélvica, utilizando la tomografía computarizada, sin influencia del posicionamiento de la pelvis con relación a la ampolla de rayos x. Métodos: Fueron evaluados, de modo aleatorio, 13 exámenes de TC de columna lumbosacra, abdomen total o pelvis, pues engloban el sacro y cabezas femorales. Todos los exámenes se realizaron en aparatos multicanales con seis canales. Se utilizó la técnica de superposición de imágenes, común en otros exámenes musculoesqueléticos como TT-TG. Se seleccionó el corte sagital centrado de la cabeza femoral izquierda, centro de S1 y centro de la meseta de S1 y cabeza femoral derecha. A partir de entonces, fue creada una cuarta imagen, análoga a una radiografía de la pelvis, en que fueron realizadas las medidas, utilizando el software dedicado. Resultados: De los 13 exámenes, tres eran de columna lumbar y 10 de abdomen total, siendo que seis eran del sexo masculino. El promedio de edad fue de 56 años. El promedio de la IP fue de $45^{\circ}$, variando entre 31 y 81 . Entre las mujeres, el promedio fue de $52^{\circ}\left(31\right.$ a $\left.81^{\circ}\right)$ y entre los hombres de $38^{\circ}(32$ y 46 ). Conclusión: La TC puede ser utilizada para el cálculo de la IP, utilizando la técnica de superposición de imágenes común en otros exámenes musculoesqueléticos como TT-TG. Nivel de Evidencia IIIB. Estudio diagnóstico. Estudio retrospectivo.

Descriptores: Tomografía computarizada por rayos X; Columna vertebral; Escoliosis; Diagnóstico por imagen. 


\section{INTRODUCTION}

Sagittal balance of the spine is comprised of a series of related segments that allow human beings to remain in a standing position with the least possible energy expenditure. ${ }^{1}$ The pelvis, in turn, is very important in this process, serving as the link that connects the spine and the lower limbs. ${ }^{1,2}$

In 1998, Lagaye and Duval-Beaupère ${ }^{3}$ described the pelvic parameters that allowed a better understanding of the shape and orientation of the pelvis and how these influence spinal alignment and lumbar lordosis. ${ }^{3,4}$ The most important of these parameters is pelvic incidence $(\mathrm{PI})$, which is an angular measurement that describes the relationship between the upper plateau of the sacrum and the femoral heads. It is considered a constant morphological measurement for each individual ${ }^{1}$ and so is used as a basis for the calculation of normal lumbar lordosis and in surgical planning. ${ }^{4}$

However, although it is described as an anatomical measurement that is not influenced by the positioning of the patient, in the two-dimensional radiographical examination the projection of the pelvis, which is a three-dimensional structure, may be influenced by its positioning in relation to the X-ray tube during image acquisition..$^{5}$ This was demonstrated by Tyrakowski, ${ }^{5}$ who showed that the rotation of the pelvis in the axial plane can lead to changes in PI values, and by Chen, ${ }^{6}$ who demonstrated variations in this measurement when a total spinal radiograph was compared to a radiograph centered on the pelvis.

New technologies, such as full-body radiographs with the EOS system, allow the minimization of this variable in PI measurements, ${ }^{7}$ but are not widely used worldwide, especially in our region.

The object of this study is to describe a more accurate way to measure the angle of pelvic incidence using computed tomography, without the influence of the positioning of the pelvis in relation to the X-ray tube.

\section{METHODS}

Following approval by the local Institutional Review Board (2.887.742), thirteen computed tomography examinations of the total abdomen, pelvis, or lumbar spine were randomly selected to describe the method for measuring PI using CT. These examinations were chosen because they included the lumbosacral junction and femoral heads, allowing the calculation of PI.

All the examinations were performed with SOMATOM Emotion 6 six-channel scanners (Siemens Medical System, Inc., NJ), according to a protocol of $1.25 \mathrm{~mm}$ thickness, $1.0 \mathrm{~mm}$ collimation, with an increment of $0.8 \mathrm{~mm}$. The sections were acquired in helical mode, with coverage of $35 \mathrm{~cm}$ in 40 seconds (FOV of $25 \times 25 \mathrm{~cm}$ ), followed by multiplanar reconstruction (MPR) in the axial, sagittal, and coronal planes of the pelvis using a B-60 filter. The technique used was $130 \mathrm{kV}$ and $150 \mathrm{~mA}$. The examinations were performed using bone window settings (W1500, C450).

\section{Tomography-based incidence measurement}

The $\mathrm{Pl}$ angle is measured between a line orthogonal to the upper plateau of $\mathrm{S} 1$ and a line that connects the center of the femoral heads to the midpoint of the plateau of $\mathrm{S}^{3}$ (Figure 1). Thus, the measurement depends on four anatomical references: the two femoral heads, the center of the plateau of S1, and its inclination. However, when the three-dimensional volumetric reconstruction is performed there is an overlap of the iliac wing in relation to the sacrum, making it impossible to measure (Figure 2). To solve the problem, image overlap, which is a technique commonly used in other musculoskeletal exams, such as measuring the TT-TG (tibial tuberosity-trochlear groove) to evaluate patellar instability, was considered. ${ }^{8,9}$

Thus, sagittal sections centered on the left femoral head, the center of the upper S1 plateau, and the right femoral head were selected from the multiplanar reconstruction. These images were superimposed and a new image was created (Figure 3), analogous to a lateral radiograph of the lumbosacral region, but without the axial rotation of the femoral heads ${ }^{5}$ and without the problem of $X$-ray divergence that occurs when total spine radiography is performed (tube not aligned

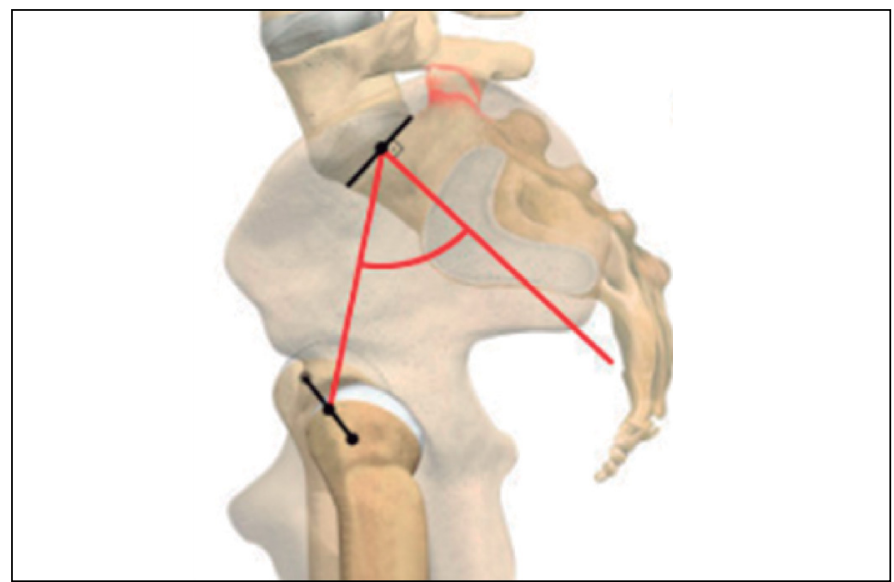

Figure 1. Pl angle - measured between a line orthogonal to the upper plateau of $\mathrm{S} 1$ and a line that connects the center of the femoral heads to the midpoint of the $\mathrm{S} 1$ plateau.

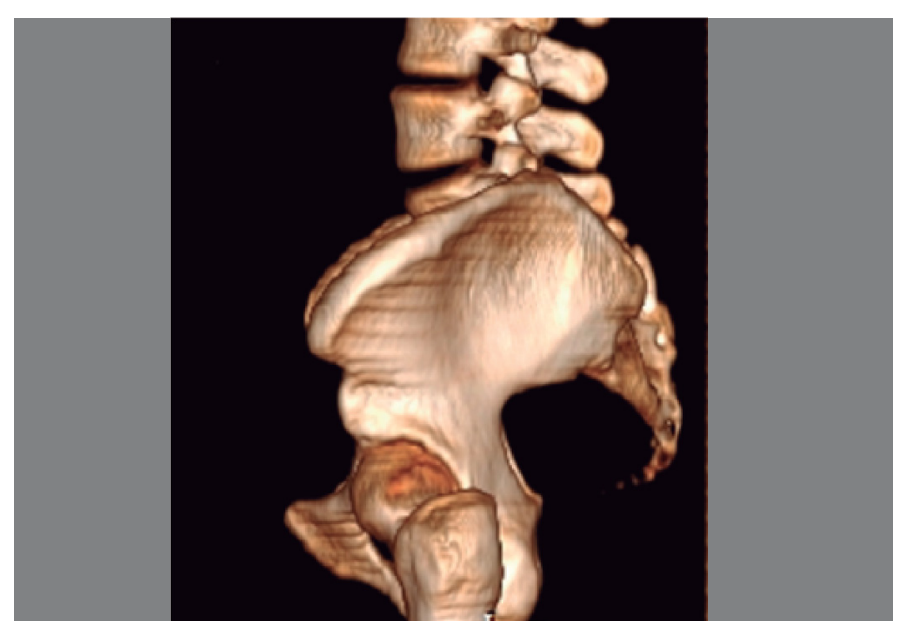

Figure 2. Volumetric CT reconstruction showing the overlap of the iliac wing, making visualization of the $\mathrm{S} 1$ plateau impossible.

with the pelvic region). ${ }^{6}$ From this new image, the PI was calculated in the usual way using SURGIMAP software (Nemaris Inc., New York, $N Y)^{10}$ dedicated to this type of calculation (Figure 4).

Because this study was focused on a description of the radiographic measurement technique, no statistical comparison was made between the sexes or groups and there was no need to complete the ICF.

\section{RESULTS}

Ten total abdomen and three lumbar spine scans were analyzed. Of these, six were of males and seven of females. The mean age of the patients was 56 years (ranging from 11 to 83 years of age) (Table 1).

The mean $\mathrm{PI}$ was $45^{\circ}$, ranging from 31 to 81 . Among the women the mean was $52^{\circ}\left(31\right.$ to $\left.81^{\circ}\right)$ and among the men it was $38^{\circ}\left(32\right.$ to $\left.46^{\circ}\right)$.

Because this is a pilot study to describe the method, all the examinations were evaluated by the lead author, including the manipulation of the images and the confection of the new image based on the addition of the three sections (centered of the left femoral head, the plateau of S1, and centered on the right femoral head). As with the TT-TG, this process is many times performed by the radiology technician, which can be done to optimize the time of the medical team.

We did not find any case in which the measurement could not be taken or where it was necessary to change the quality of the images (brightness, contrast, etc.) in order to better visualize the anatomical markers. In the more elderly patients, there was a slight increase in the difficulty in analyzing the images because of the presence of advanced osteoarthrosis (Figure 5). 


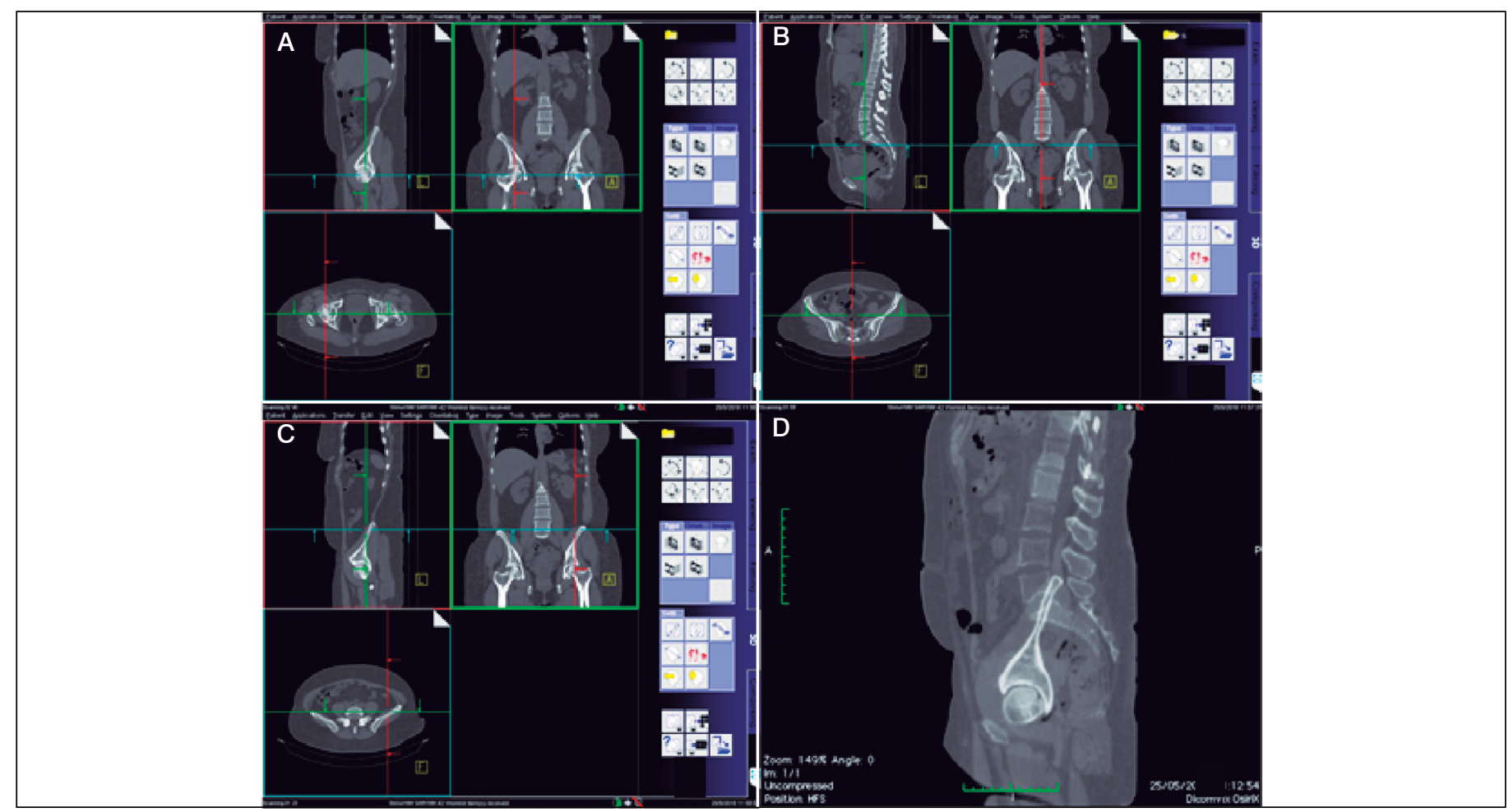

Figure 3. Selection of images in the sagittal plane from the multiplanar reconstruction: A - sagittal image centered on the right femoral head; B - sagittal image centered on the upper plateau of $\mathrm{S} 1$; $\mathrm{C}$ - sagittal image centered on the left femoral head; D - Overlap of the three, creating a new image analogous to the lateral pelvic radiograph.

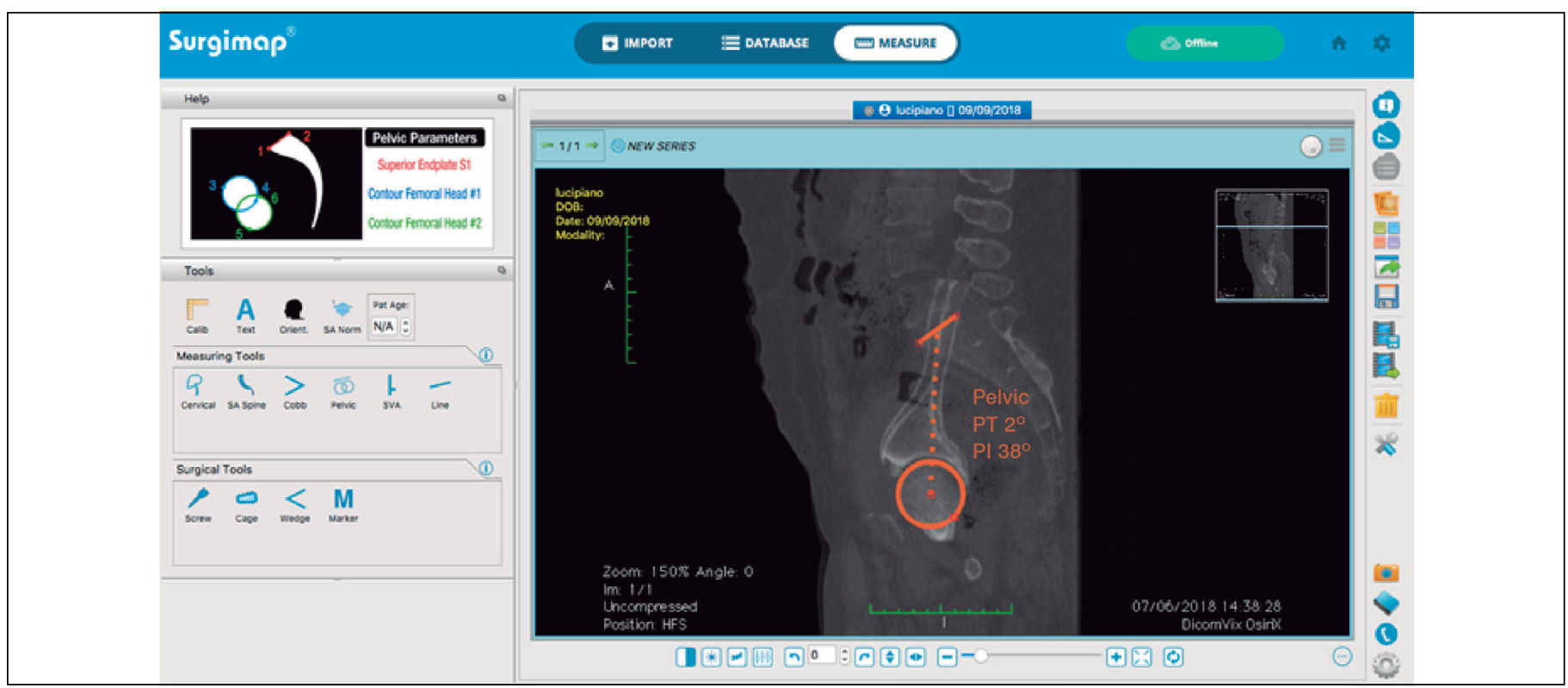

Figure 4. Measurement of the PI angle using the software dedicated to this type of measurement in the image created from the composite of the three images, analogous to a lateral radiograph of the lumbosacral region.

\section{DISCUSSION}

The measurement of pelvic incidence is fundamental to surgical planning for patients undergoing spinal surgery. Because it is a morphological measurement that is not influenced by the positioning of the individual, it is used in the calculation of the patient's normal lumbar lordosis. ${ }^{4}$

However, it is not uncommon in daily practice for us to observe changes in the PI values in the same individual when we use pre- and postoperative radiographs and even during postoperative follow-up. This observation inspired us to look for a more accurate way to perform this measurement, since, by definition, this angle should be constant considering that there is no movement in the sacroiliac joint. ${ }^{3}$

The explanation for this variability is because the projection of the pelvis, a three-dimensional structure, is influenced during the two-dimensional radiographic examination by the positioning of the patient in relation to the X-ray tube and the film. ${ }^{5}$

This was demonstrated by Tyrakowski, ${ }^{5}$ who evaluated the influence of pelvic rotation in the axial plane on the PI measurement. In this study, using radiographs of a model of the pelvis, the author showed that with a pelvic rotation of up to $35^{\circ}$ the $\mathrm{PI}$ is still acceptable, which for the author would be a change of up to $6^{\circ}$. Although 
Table 1. Demographic data and type of examination used for evaluation.

\begin{tabular}{c|c|c|c}
\hline Type of examination & sex & age & PI \\
\hline Lumbar spine CT & M & 52 & 38 \\
\hline Lumbar spine CT & F & 79 & 81 \\
\hline Lumbar spine CT & F & 32 & 60 \\
\hline Total abdomen CT & M & 83 & 46 \\
\hline Total abdomen CT & F & 38 & 55 \\
\hline Total abdomen CT & M & 61 & 32 \\
\hline Total abdomen CT & M & 76 & 34 \\
\hline Total abdomen CT & F & 76 & 60 \\
\hline Total abdomen CT & F & 11 & 31 \\
\hline Total abdomen CT & M & 45 & 34 \\
\hline Total abdomen CT & M & 81 & 42 \\
\hline Total abdomen CT & F & 47 & 36 \\
\hline Total abdomen CT & F & 59 & 40 \\
\hline Mean & & 56 & 45 \\
\hline Minimum & & 11 & 31 \\
\hline Maximum & & 83 & 81 \\
\hline
\end{tabular}
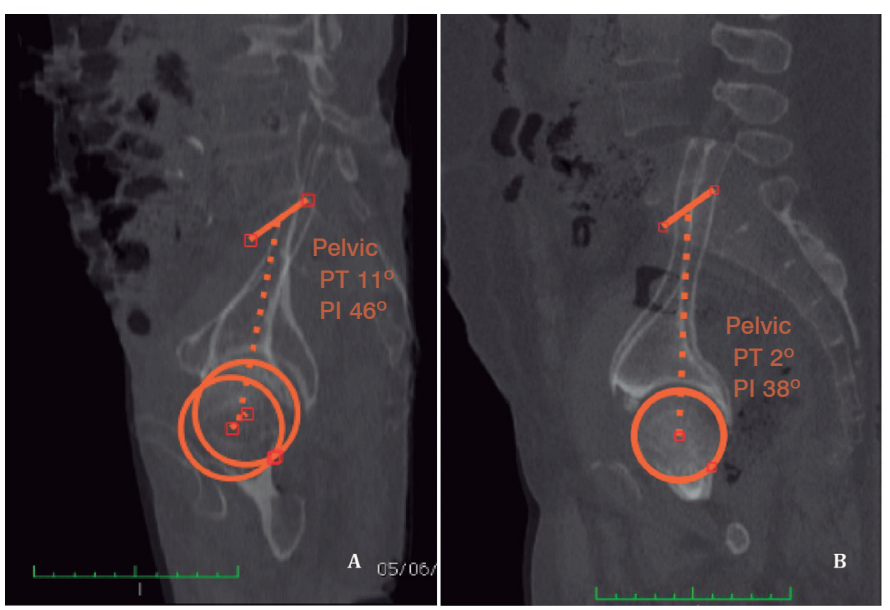

Figure 5. Patient A, 83 years old, and patient B, 52 years old, showing how the presence of osteoarthrosis makes it slightly more difficult to see the anatomical references. $35^{\circ}$ is a relatively high rotation, this can happen in some patients, especially those with deformities. In addition, the value of $6^{\circ}$ can be a significant difference, particularly in relation to a measurement as important as $\mathrm{PI}$, which is the basis for the calculation of other parameters, including lumbar lordosis. Finally, the authors used radiographs centered on the pelvis, which does not allow an evaluation of the variation due to the divergence of the $X$-rays that occurs in full-spine radiographs, which today is the examination of choice for calculating these measurements.

This assessment was conducted by Chen, ${ }^{6}$ who compared the values of the pelvic parameters measured in full-spine radiographs with lateral pelvic radiographs. This author showed that lateral pelvic radiographs enabled better inter- and intraobserver reliability in $\mathrm{PI}$ measurements, even though the angle differences were small when comparing the two methods. During the study, both examinations were conducted at the same time, with the patient in the same position, which does not often happen in real life and may contribute to this small difference in the angles. For the author, the better reliability of the lateral pelvic radiograph is due to the X-ray tube being centered in the pelvis, allowing visualization with the overlap of the femoral heads, in addition to permitting a more suitable X-ray intensity for the region, allowing sharper image viewing.

Measurement using CT minimizes all those factors that are considered responsible for reduced accuracy of the measurement since it is performed with the overlapping of the heads both in the coronal and sagittal planes and with the sharpness of tomography, far superior to that of conventional radiography. One disadvantage of the method is the high radiation load, although tomography of the region is already part of the propaedeutics of most patients who will undergo some type of spinal surgery, especially those with deformities that require some type of correction.

New technological advances, such as EOS probably allow the same measurement accuracy as CT, however, it is still a very expensive technology with very low availability.

\section{CONCLUSIONS}

The measurement of the $\mathrm{PI}$ is very important for the calculation of lumbar lordosis and for surgical planning in patients with lumbar spine pathology. CT can be used to calculate this measurement, using the technique of overlaying images common to other musculoskeletal examinations, such as TT-TG.

All authors declare no potential conflict of interest related to this article.

CONTRIBUTION OF THE AUTHORS: All authors made significant individual contributions to this manuscript. MTD was the creator of the study and the methodology. RTD and RTD are radiologists and helped to create the measuring method. NCM, VNN and PFJ assisted with data collection. RFSL and RVTF conducted the bibliographical review. MFR assisted with the preparation of the manuscript.

\section{REFERENCES}

1. Roussouly P. Pinheiro-Franco JL. Biomechanical analysis of the spino-pelvic organization and adaptation in pathology. Eur Spine J. 2011;20(5):609-18.

2. Pratali R, Diebo B, Schwab F. Adult Spine Deformity-An Overview Of Radiographic And Clinical Considerations. Coluna/Columna. 2017;16(2):149-52.

3. Legaye J, Duval-Beaupere G, Hecquet J, Marty C. Pelvic incidence: a fundamental pelvic parameter for three-dimensional regulation of spinal sagittal curves. Eur Spine J. 1998;7(2):99-103.

4. Schwab F, Lafage V, Patel A, Farcy JP. Sagittal plane considerations and the pelvis in the adult patient. Spine (Phila Pa 1976). 2009;34(17):1828-33

5. Tyrakowski M, Wojtera-Tyrakowska D, Siemionow K. Influence of pelvic rotation on pelvic incidence, pelvic tilt, and sacral slope. Spine (Phila Pa 1976). 2014;39(21):E1276-83.

6. Chen RQ, Hosogane N, Watanabe K, Funao H, Okada E, Fujita N, et al. Reliability analysis of spino-pelvic parameters in adult spinal deformity: a comparison of whole spine and pelvic radiographs. Spine (Phila Pa 1976). 2016;41(4):320-7
7. Okamoto M, Jabour F, Sakai K, Hatsushikano S, Le Huec JC, Hasegawa K. Sagittal balancemeasures are more reproducible when measured in $3 D$ vs in $2 D$ using full-body EOS $B$ images. Eur Radiol. 2018;28(11)4570-7.

8. Jones RB, Bartlett EC, Vainright JR, Carroll RG. CT determination of tibial tubercle lateralization in patients presenting with anterior knee pain. Skeletal Radiol 1995;24(7):505-9.

9. Smith TO, Davies L, Toms AP, Hing CB, Donell ST. The reliability and validity of radiological assessment for patellar instability. A systematic review and meta-analysis. Skeletal Radiol. 2011;40(4):399-414.

10. Vila-Casademunt A, Pellisé F, Acaroglu E, Pérez-Grueso FJ, Martín-Buitrago MP, Sanli T, et al. The reliability of sagittal pelvic parameters: the effect of lumbosacral instrumentation and measurement experience. Spine (Phila Pa 1976). 2015;40(4):E253-8. 